\title{
Periodic Inspections of Residential Heating Appliances for Solid Fuels - Concept of National Periodic Inspection System
}

\author{
Jolanta Telenga-Kopyczyńska', Katarzyna Rychlewska1* \\ 1 Institute for Chemical Processing of Coal, ul. Zamkowa 1, 41-803 Zabrze, Poland \\ * Corresponding author's e-mail: krychlewska@ichpw.pl
}

\begin{abstract}
The article introduces the concept of individual solid fuel heating devices periodic inspections system. The necessary legal changes for the creation of the legal framework of the system, the proposed scope of control, persons who could be entrusted with the realization of periodic inspections and measurements, as well as data acquisition and possible sanctions for non-compliance or violation of proposed duties were presented.
\end{abstract}

Keywords: legal regulations, periodic inspections, solid fuel boilers, solid fuel space heaters.

\section{INTRODUCTION}

Currently in Poland there are no legal regulations regarding periodic inspections of residential solid fuel heating appliances in terms of their technical conditions, safe and environmentally-friendly operation and the "real conditions" emissions of air pollutants.

The inspections carried out under the Art. 23 of the Act of 29 August 2014 on Energy Performance of Buildings [1] include the assessment of the technical condition of the heating system, taking into account the energy efficiency of boilers and adequacy of their heat output to building needs. Pursuant to the provisions of the Act, there is an obligation to order the said inspection at least once every five years, which rests with the owners and users of buildings, where solid fuel boilers with a rated heat output of 20 to $100 \mathrm{~kW}$ are operated. Therefore, the Act does not cover a wide range of solid fuel boilers with a rated heat output below $20 \mathrm{~kW}$, very often installed in residential buildings.

In turn, inspections of compliance with the air quality protection regulations, including those introduced by so-called "anti-smog resolutions" [2], provisions of the Act of 14 December 2012 on waste [3] and the Act of 13 September 1996 on Maintaining Cleanliness and Order in Municipalities [4] carried out by municipal/city guards or Local Government Units employees pursuant to Art. 379 of the Act of 27 April 2001, The Environmental Protection Law [5] in terms of compliance with the municipal waste management rules and prohibition of waste incineration/co-incineration in households, burning substandard solid fuels or fuels banned by local and national acts and ordinances, as well as approved for installation boilers and local space heaters, are carried out mostly in the "intervention mode".

In addition, the afore-mentioned provisions of the Art. 379 of the Act of 27 April 2001, The Environmental Protection Law sets very general requirements, without specifying minimum requirements, even with regard to such important issues as the frequency or the protocol template specifying the minimum scope of control activities or methodological requirements (i.e. waste incineration detection). Moreover, the provisions of Art. 379 do not introduce any minimum competence requirements to be met by the inspection services authorized by the commune authorities.

A detailed analysis of the legal regulations in force in selected European countries [6] allowed for the formulation of initial assumptions which, after the introduction of relevant amendments to 
the national legal acts, may constitute the legal framework for the small solid fuel firing appliances periodic inspections system, including both, technical conditions assessment and measurement of "real operation" emissions of pollutant, as well as mandatory user's training in the field of solid fuel combustion theory and lowemission heat source operation.

The article discusses the legal changes necessary to introduce in order to create the legal framework of the system. The proposed scope of inspections, proposed inspection services, as well as possible sanctions for non-compliance or violation of the provisions proposed in the concept were presented.

\section{CURRENT LEGAL STATUS AND IDENTIFICATION OF SHORTCOMINGS}

In recent years, at the EU and national level, the minimal requirements for boilers and local space heaters for solid fuels, when placing them on the market, have been introduced $[7 \div 9]$. Moreover, the market of coal solid fuels intended for combustion in household and municipal sectors [10] was also regulated by establishing the minimum national quality requirements [11], as well as bans for the combustion of certain types of solid fuels or solid fuels in general in order to protect the quality of the air. Anti-smog resolutions, in force in most Voivodships [2], also oblige citizens to successively replace outdated, high-emission heating devices with new ones, that meet the requirements of class 5 in accordance with the PN-EN-303-5 standard [12] (in the case of Silesian Voivodship) or requirements of the Ecodesign directives [8,9]. Undoubtedly, a breakthrough in the air quality management at national level is the amendment to the Act of 21 November 2008 on Supporting Thermomodernization and Renovations [13]. Pursuant to Chapter 5a of the Act, the Central Register of Building Emissions (CRBE) will be established, which will constitute a nationwide system for household and municipal sectors heat sources inventory, including solid fuel combustion sources with a nominal heat output of up to $1 \mathrm{MW}$. The register will collect the data on the intended use of the source, type and amount of fuel burned and the results of statutory inspections, including annual chimneys and flue gas discharge systems inspections, in accordance with Art. 62 of the Act of July 71994 - the Construction Law [14] and inspections pursuant to Art. 379 of Environmental Protection Law Act. Moreover, the provisions of the Art. $27 \mathrm{~g}$ of the Act oblige citizens to notify the commune authorities about the solid fuel device installed in the building. According to the Communication from the Minister of Economic Development, Labour and Technology [15] of 25 March 2021, the submission of declarations will start on 1 July 2021. In line with the Art. 15 of the Act of 28 October 2020 amending the Act on Supporting Thermo-modernization and Renovations and some other acts [16], there will be 12 months from the day of Communication releasement for reporting the existing heating devices. In the case of new ones, the notification must be made within 14 days of its commissioning.

The provisions on CRBE undoubtedly constitute a milestone in the fight against "low emissions" in Poland, since the lack or low efficiency of the inventory of solid fuel combustion sources in municipalities was raised by the Supreme Audit Office [17], as one of the most important reasons for the low efficiency of initiatives and programs undertaken so far.

Nevertheless, despite the intensification of the efforts and measures to combat the "low emission", attention is drawn to the fact that the operation of small heat sources, including individual heating devices, such as boilers and local solid fuel space heaters, is not regulated at the statutory level. The introduction of a national system of periodic inspections of the technical condition and actual emissions of pollutants from the sources operated as part the of the common use of the environment, will therefore require the solving of a number of legal, competence and technical issues.

The key legal changes should include:

- Establishment of the catalog of solid fuel combustion sources with a rated thermal output of less than $1 \mathrm{MW}$, which do not require permit or notification pursuant to the provision of Art. 220 and 152 of the Act of 27 April 2001, The Environmental Protection Law, which will be covered by acceptance and periodic inspections system, including measurement of the concentration of pollutants emitted.

- The statutory definition of basic requirements for the operation of solid fuel combustion sources with a rated thermal output of less than $1 \mathrm{MW}$, to which the new law would apply.

- The statutory definition of the most important obligations imposed on the owners of solid 
fuel combustion devices with a rated thermal output of less than $1 \mathrm{MW}$, including the introduction of a statutory obligation to comply with the newly introduced emission standards determined by authorized services during acceptance and periodic inspections. Other required statutory obligation should include ensuring proper operation in accordance with a manufacturer's instruction, maintenance of a proper technical condition, operating devices only with the solid fuels intended for a given combustion source (suitable for use in accordance with the manufacturer's specifications), installing or commissioning to install a measuring hole which would comply with the requirements specified in the ordinance introducing the measuring methodology.

- Defining the frequency, scope of inspections and measurements, as well as the template of the report on its performance.

- The statutory designation of inspection services authorized to carry out inspections and maximum fees.

- Establishing the nationally uniform methodology for measuring the concentration of pollutants emitted and recognizing the standards as met.

- Statutory determination of sanctions for failure to comply with obligations.

- Amendments to the provisions on the Central Register of Building Emissions in order to extend the catalog of controls from which the data will be entered into the ICT system and to extend the functionality of the database with a new electronic form.

\section{THE OVERALL CONCEPT OF ACCEPTANCE AND PERIODIC INSPECTIONS SYSTEM}

As mentioned above, it is proposed that the system of acceptance and periodic inspections should cover the solid fuel combustion small installations with a rated thermal output of less than $1 \mathrm{MW}$, which are used in residential, commercial/institutional and agriculture/forestry sectors for the purposes of space heating and hot water preparation, for which data will be collected in the CRBE database.

The developed concept assumes that ordering the control of the fuel combustion source will be the responsibility of the owner/user of the heating device. The relevant provision establishing the owners' obligations should be introduced into the national legislation by amending the Environmental Protection Law Act by introducing a new chapter, which will be dedicated to solid fuel combustion plants with a rated thermal output of less than $1 \mathrm{MW}$.

After the installation/replacement of the solid fuel combustion source covered by the proposed regulations, the owner/user would be obliged to report this fact to the municipal authorities in accordance with the proposed amendment to the Act of 21 November 2008 on Supporting Thermo-modernization and Renovations within 14 days. These data will be entered into the Central Register of Building Emissions. As part of the developed concept, it is proposed that after submitting the declaration, the owner/user should be statutory obliged to contact the authorized services and order the acceptance inspection within 90 days of commissioning the source. Within the scope of the acceptance inspection, the correct installation of the device should be assessed, including the fitting of the flue gas discharge system and chimney to the manufacturer's requirements indicated in the device's technical and operational documentation. As part of the acceptance inspection, following other European countries example [6], the owner of the device would also be obliged to undergo training on principles of solid fuel combustion theory, low-emission operation of the device and the proper fuel storage and handling.

According to the proposed concept, the first periodic inspection would be carried out 4 years after the acceptance inspection recorded in the CRBE, and subsequent periodic inspections should be carried out every two years. In the case of failure to meet the obligation within the time-limit laid down, a reminder letter from the commune authorities with an additional deadline of 30 days would be sent to the address of the building, in which the source is located. In the case of failure to comply with the established additional time-limit, the environmental protection authority would carry out the inspection applying the Art. 379 of the Act of 27 April 2001, The Environmental Protection Law, through authorized municipal/city guards or Local Government Units employees. In such cases, the inspector authorized in accordance with proposed regulations would act as an expert.

In the case of a negative result of the periodic inspection, as a result of a failure to meet emission standards or stated significant technical deficiencies, the inspector would provide the instructions on the necessary repairs and 
changes to the installation and set a deadline for their removal. As in the case of the acceptance inspection, it would be permissible to continue the operation of the installation, provided that the recommendations specified in the inspection protocol are introduced and that the installation is subjected to a post-inspection within the time specified by the authorized inspector.

The data from the conducted acceptance, periodic and eventual post-inspection would be entered into the ICT system supporting the Central Register of Building Emissions using dedicated electronic forms. Owing to this, the commune authorities would be able to monitor the citizens' compliance with the statutory obligations on an ongoing basis.

The maximum fees for carrying out the acceptance, periodic and subsequent inspection taking into account the scope of the control, in particular the necessity to carry out the emission measurements, is proposed to be specified in the ordinance to the proposed amendment to Environmental Protection Law Act.

\section{PROPOSED INSPECTION SERVICES}

During the concept development, the inspection services taken into account were those indicated in the provisions of Art. 27b of the Act [13] as authorized to enter data into the CRBE. After analyzing the competences of individual indicated services, it was assumed, bearing in mind the necessary qualifications ensuring the proper conduction of the inspection, that acceptance and periodic inspections should be carried out by the persons with the qualifications of a master chimney sweep, persons with qualifications related to the operation and supervision of energy equipment and persons with building qualifications in installation specialization. It was found that city/ commune guards and employees of local government units may not have sufficient technical knowledge to assess the technical condition of heating devices and to train the user/owner in the topic of the solid fuel combustion process.

\section{PROPOSED SCOPE OF THE ACCEPTANCE AND PERIODIC INSPECTION}

The scope of the acceptance and periodic checks under the proposed national system should include:
- Assessment of the technical condition of the device - technical deficiencies found during the acceptance and periodic inspection, which may significantly affect the operation of the solid fuel firing device and the concentration of pollutants emitted, may constitute the basis for issuing a negative inspection result and should be removed within the time limit set by the inspector in the inspection protocol.

- Operation method - one of the proposed statutory obligations is to oblige owners/users to comply with the operation method specified in the instruction supplied with the fuel combustion source, as per regulations in force in the Czech Republic and Germany. Incorrect operation of the source, inconsistent with the instructions, may lead to both an increase in harmful emissions as well as a threat to the health and life of people and property.

- Meeting emission standards - one of elements of the proposed periodic inspection system is measurement of the concentration of particulate matter and carbon monoxide emitted. The proposed legal regulations provide for the introduction of the statutory obligation to comply with the emission standards, which, as in the case with medium and large combustion plants, will be specified in the ordinance. The particulate matter and carbon monoxide emission standards should be established differently for particular groups of heating devices covered by the periodic inspection system. Due to the dynamics of changes in national regulations and acts of local law introduced in recent years, forcing the need to replace heat sources, as well as regulations of programs co-financing the change of heating method, it would be necessary to introduce the emission standards that would be adapted to the diverse and dynamically changing structure of individual heating in the country and would take into account the transition periods introduced in anti-smog resolutions. The emission standards specified in the regulations setting the requirements for heating devices when placing them on the market may not be achieved under real operating conditions, especially in the case of the devices operated contrary to the instructions for a long period of time. The concept assumes that emission standards would be introduced only for solid fuel boilers.

- In the case of local space heaters, the verification of compliance with the legal requirements 
would only include the inspection of the technical documentation provided by the manufacturer. Due to the high complexity of measurements of emissions from this type of devices, the development of a methodology that allows obtaining reliable results under the conditions of measurements carried out outside a specialized laboratory is a very difficult task.

- Due to the statutory nature of the introduced measurements and sanctions to which the owners of the devices may be subject, it will be necessary to introduce stringent guidelines regarding the maintenance and certification of measuring equipment, especially due to the measurement of dust, which is a complicated task.

- Control of combusted fuel and the manner of its storage - the inspector should check whether the combusted fuel complies with the requirements set out in the Regulation of the Minister of Energy on quality requirements for solid fuels and whether it complies with the provisions of the anti-smog resolution, if applicable in a given area. In addition, the inspector should verify that the fuel quality parameters are consistent with the fuel parameters indicated by the manufacturer in the operation and maintenance documentation for, which compliance with the emission limit values has been confirmed. Such control should be carried out on the basis of the documents held by the owner containing the information on the quality parameters of the fuel and the data on the packaging, which the entrepreneur placing fuels on the market is obliged to hand over to each buyer of the fuel according to the Art. $6 \mathrm{c}$ of the Act of 25 August 2006 on the fuel quality monitoring and control system. The proposed legislation changes propose the introduction of a statutory obligation to burn fuels that meet the requirements specified in the equipment documentation and the obligation for the owner to keep the fuel quality certificate obtained at the time of fuel purchase. The inspector should also visually assess the fuel assortment, the presence of foreign material and measure the moisture content in the case of lump wood.

- Operation training - during the acceptance inspection in relation to a new heating device and during the first periodic inspection in the case of heating devices put into operation before the entry into force of regulations, the owner should be statutory obliged to undergo a training in the basics of the combustion of solid fuels, low-emission boiler operation and proper storage and handling of solid fuels.

\section{INSPECTION PROTOCOLS}

The proposed concept assumes the preparation of two inspection protocols - an electronic one entered into the Central Register of Building Emissions via the dedicated electronic form, prepared using IT systems supporting the central database, as well as a shortened paper protocol, a copy of which will be handed over to the owner of inspected heating device. Protocols templates are proposed to be specified in the ordinance to the act introducing the Central Register of Building Emissions.

\section{OFFENSES AND SANCTIONS}

The concept provides for the introduction of new criminal provisions, which would define the offenses subject to a fine, consisting in the breach of the obligation to use only the fuels intended for a given source, breach of the obligation to keep the quality certificate of the solid fuel used, and failure to comply with the obligation to commission an acceptance, periodic and subsequent source inspection. It would be reasonable to introduce a provision authorizing city/municipal guards to impose fines for the abovementioned offenses by way of a criminal mandate.

In addition to the criminal sanctions, the concept also assumed the introduction of an administrative sanction consisting in an order to suspend the operation of the installation. However, it is assumed, that a protective period will be introduced for the devices that are the main source of space heating and domestic hot water preparation, which coincide with the heating period. Moreover, the suspension order would not be enforced in the event of a positive inspection result without the expiry of the time limit specified by the inspector/local environmental protection authority. If the owner fails to comply with the order to suspend the operation, the proposed regulation provides for the penalty of arrest or restriction of liberty, or a fine.

\section{CONCLUSIONS}

The introduction of periodic inspections and measurements is an effective way to increase the awareness of solid fuels firing installations owners about the impact of duplicated, most often due to the insufficient knowledge and bad practices resulting in very high concentrations of pollutants 
emitted. Regular inspections, in conjunction with emission measurements, also allow visualizing the effects of bad practices with subsequent training of owner and errors correction. Furthermore, it is possible to introduce appropriate measures for a specific situation, and thus - much more effective remedial measures allowing for a much more effective fight against the low emission phenomenon that is harmful to human life and health.

Legal sanctioning of periodic inspections of small heat sources should take place at the earliest after activating all functionalities of the CRBE base. It should also be preceded by the recognition of the structure of the use of solid fuel boilers in the household and municipal sector based on the data from the inventory contained in the database, including at least $50 \%$ of residential premises. It will also be of key importance to develop the emission standards, the values of which will minimize the impact of the individual heating sector on the air quality, but at the same time will be possible to meet under real operation conditions. It will also be necessary to develop a methodology for measuring the concentration of pollutants emitted, which will be applicable under the conditions prevailing in domestic boiler rooms, ensuring the highest possible reliability and repeatability of the obtained results. Before introducing the control system, it may also be necessary to introduce the legal solutions that will ensure proper preparation of heating devices for periodic measurements and equipping them with a measuring hole in the pipe connecting the boiler with the chimney.

\section{Acknowledgments}

The work was carried out as part of the research and development project "Zintegrowany system wsparcia polityki i programów Ograniczenia Niskiej Emisji - ZONE" co-financed by the National Center for Research and Development under the GOSPOSTRATEG Strategic Program of scientific research and development (contract number Gospostrateg1/385807/4/2018/NCBR).

\section{REFERENCES}

1. Ustawa z dnia 29 sierpnia 2014 r. o charakterystyce energetycznej budynków (tekst jednolity ustawy Dz.U. 2020 poz. 213).

2. https:// pols ki a la r m s mogowy.p l/ jak-wygrac-ze-smogiem/uchwaly-antysmogowe/.

3. Ustawa z dnia 14 grudnia 2012 r. o odpadach (tekst jednolity ustawy Dz. U. 2019 poz. 701).
4. Ustawa z dnia 13 września 1993 r. o utrzymaniu czystości i porządku w gminach (tekst jednolity ustawy Dz. U. 2019 poz. 2010).

5. Ustawa $z$ dnia 21 kwietnia 2001 r. - Prawo ochrony środowiska (tekst jednolity ustawy Dz.U. 2020 poz. 1219).

6. Rychlewska K., Telenga-Kopyczyńska J., Bigda R, Żeliński J. 2021. Periodic inspections of residential heating appliances for solid fuels: Review of legal regulations in selected European Countries. Journal of Ecological Engineering, 22(2), 54-62.

7. Rozporządzenie Ministra Rozwoju z dnia 30 grudnia 2019 r. w sprawie wymagań dla kotłów na paliwo stałe z późn. zm. (Dz.U. 2019 poz. 2549).

8. Rozporządzenie Komisji (UE) 2015/1189 z dnia 28 kwietnia 2015 r. w sprawie wykonania dyrektywy Parlamentu Europejskiego i Rady 2009/125/WE w odniesieniu do wymogów dotyczących ekoprojektu dla kotłów na paliwo stałe (Dz. Urz. UE L 193/100 z 21.7.2015).

9. Rozporządzenie Komisji (UE) 2015/1185 z dnia 24 kwietnia 2015 r. w sprawie wykonania dyrektywy Parlamentu Europejskiego i Rady 2009/125/WE w odniesieniu do wymogów dotyczących ekoprojektu dla miejscowych ogrzewaczy pomieszczeń na paliwo stałe (Dz. Urz. UE L 193/1 z 21.7.2015).

10. Ustawa z dnia 25 sierpnia 2006 r. o systemie monitorowania i kontrolowania jakości paliw (tekst jednolity ustawy Dz. U. 2019 poz. 660).

11. Rozporządzenie Ministra Energii z dnia 27 września 2018 r. w sprawie wymagań jakościowych dla paliw stałych (Dz. U. 2018 poz. 1890).

12. PN-EN 303-5:2012. Kotły grzewcze - Część 5: Kotły grzewcze na paliwa stałe $\mathrm{z}$ ręcznym $\mathrm{i}$ automatycznym zasypem paliwa o mocy nominalnej do $500 \mathrm{~kW}$ Terminologia, wymagania, badania i oznakowanie.

13. Ustawa z dnia 21 listopada 2008 r. o wspieraniu termomodernizacji i remontów oraz o centralnej ewidencji emisyjności budynków (tekst jednolity ustawy Dz. U. 2021 poz. 554).

14. Ustawa z dnia 7 lipca 1994 r. - Prawo budowlane (tekst jednolity ustawy Dz.U. 2020 poz. 1333).

15. Komunikat Ministra Rozwoju, Pracy i Technologii z dnia 25 marca 2021 r. w sprawie określenia dnia wdrożenia rozwiązań technicznych umożliwiających złożenie deklaracji o źródłach ciepła lub źródłach spalania paliw z wykorzystaniem systemu teleinformatycznego obsługującego centralną ewidencję emisyjności budynków (Dz. U. 2021 poz. 583).

16. Ustawa z dnia 28 października 2020 r. o zmianie ustawy o wspieraniu termomodernizacji i remontów oraz niektórych innych ustaw (Dz. U. 2020 poz. 2127).

17. Najwyższa Izba Kontroli. Ochrona powietrza przez zanieczyszczeniami. Informacje o wynikach kontroli LKR-4101-007-00/2014. Warszawa, 2018. 